https://www.journal-imab-bg.org

Original article

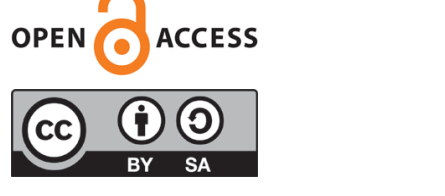

\title{
EFFECTIVENESS OF PRIMARY INTRA- OSSEOUS ANESTHESIA IN THE ENDODONTIC TREATMENT OF MANDIBULAR MOLARS WITH IRREVERSIBLE PULPITIS
}

\author{
Emiliya Simeonova ${ }^{1}$, Snezhana Tsanova ${ }^{1}$, Plamen Zagorchev ${ }^{2}$ \\ 1) Department of Operative Dentistry and Endodontics, Faculty of Dental Medi- \\ cine, Medical University of Plovdiv, Bulgaria \\ 2) Department of Medical Physics and Biophysics, Faculty of Pharmacy, Medi- \\ cal University of Plovdiv, Bulgaria.
}

\section{ABSTRACT}

Objective: The aim of the study was to investigate the effectiveness of primary intraosseous anesthesia (IO) in the endodontic treatment of lower molars with irreversible pulpitis.

Material and method: The subject of the study was 30 clinically healthy patients diagnosed with irreversible pulpitis of mandibular first or second molars. All of endodontic treatments were performed in a single visit. IO was performed with computer assisted system Quicksleeper. Our goal was to investigate the presence of pain during various parts of endodontic treatment with Visual Ana$\log$ Scale. The pain level was registered at the end of the following parts of the endodontic treatment: 1 -st part - after preparation of the endodontic access; 2-nd part - after determining the working length for all root canals; 3-rd part - after root canal preparation.

Results: No pain was registered either in preparation of endodontic access or in determining the working length for all root canals. Only four patients $(14.3 \%)$ registered mild pain during root canal preparation, which did not interfere of the endodontic treatment. In the 3-rd part of endodontic treatment it was registered moderate and severe pain respectively from $3.5 \%$ and $7.2 \%$ of patients, requiring a supplemental anesthesia.

Conclusion: The IO can be use as primary method of analgesia that provides reliable pulpal anesthesia for routine endodontic treatment.

Keywords: intraosseous anesthesia, Quicksleeper, irreversible pulpitis, Inferior alveolar nerve block,

\section{INTRODUCTION}

Achieving adequate pulpal anesthesia in the mandibular molars can often be a challenge to the clinician [1]. The most commonly used method for mandibular anesthesia in adult patients is the conventional Inferior alveolar nerve block (IANB) [2]. IANB is not $100 \%$ successful in the endodontic treatment of lower molars with irreversible pulpitis. It is reported that the failure of IANB of mandibular molars with intact pulp is about 5-15\% and with irreversible pulpitis - about $44-81 \%[3,4,5]$. This may be due to both inaccurate performance of anesthesia technique and patient-related factors (such as anatomical, pathological or physiological) [6]. Therefore, it is necessary to use supplemental anesthetic techniques such as intraligamentary, intrapulpal and IO.

The use of IO was described by Lilienthal in 1975 and this author notes the reluctance at that time of operators to use the method. Since that time, specialized delivery systems have been introduced and this may increase the acceptance of the technique [4].

The IO involves perforating the osseous cortex to enable infiltration of local anesthetic within the cancellous bone where it can readily diffuse to anesthetize the sensory nerves of teeth. Nowadays, IO finds application as a primary technique of analgesia thanks to the improvement of intraosseous delivery systems such as the computer assisted system Quicksleeper.

\section{OBJECTIVE}

The aim of the study was to investigate the effectiveness of primary IO in the endodontic treatment of lower molars with irreversible pulpitis. 


\section{MATERIAL AND METHOD}

The study was approved by the Ethical Committee of Medical University of Plovdiv (No. 6/10. 11. 2016). Written informed consent was obtained from every subject.

The subject of the study was 30 clinically healthy patients visited the Faculty of Dental Medicine - Plovdiv, Bulgaria and diagnosed with irreversible pulpitis of mandibular first or second molars. All of endodontic treatments were performed in a single visit. IO was performed with computer assisted system Quicksleeper (Dental Hi Tec, Cholet Cedex, France) (figure 1) in the following steps:

Fig. 1. Computer assisted system Quicksleeper.

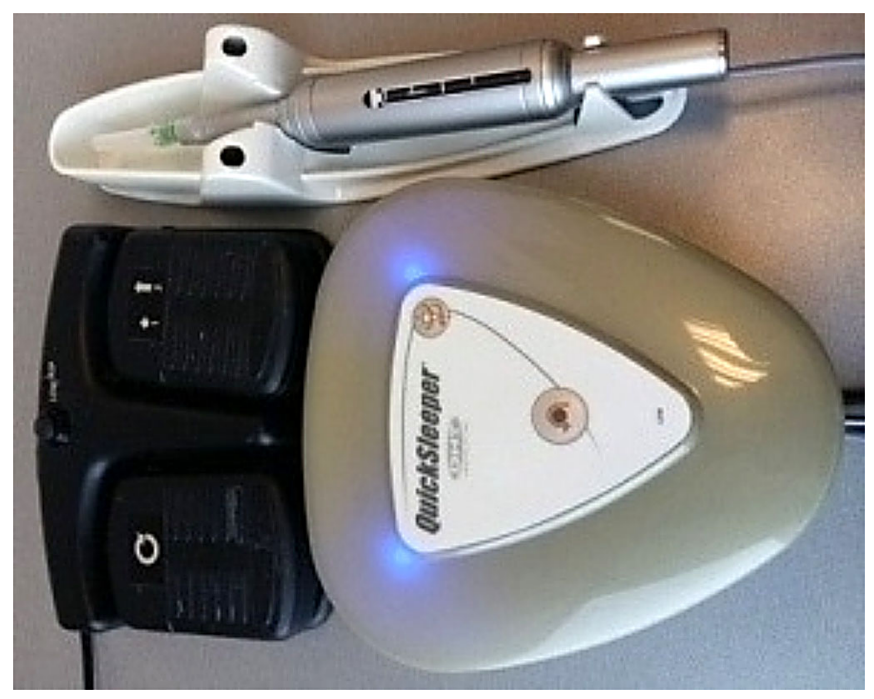

- infiltrative anesthesia of soft tissue $-0.3 \mathrm{~mL}$ anesthetic (4\% articaine hydrochloride with 1:100 000 adrenaline) was infiltrated at an angle of $15^{\circ}$ to the bone at the target point for perforating the compact bone (figure 2);

Fig. 2. Infiltrative anesthesia.

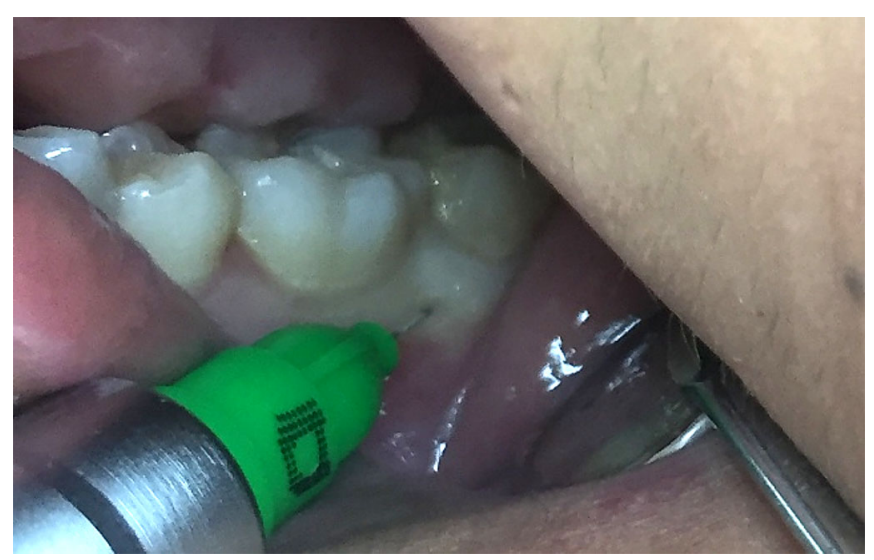

- perforation of compact bone - target point of the compact bone's perforation was $2 \mathrm{~mm}$ apical from the intersection of the horizontal and vertical line always distal of the first molar (figure 3);

Fig. 3. Intraosseous anesthesia.

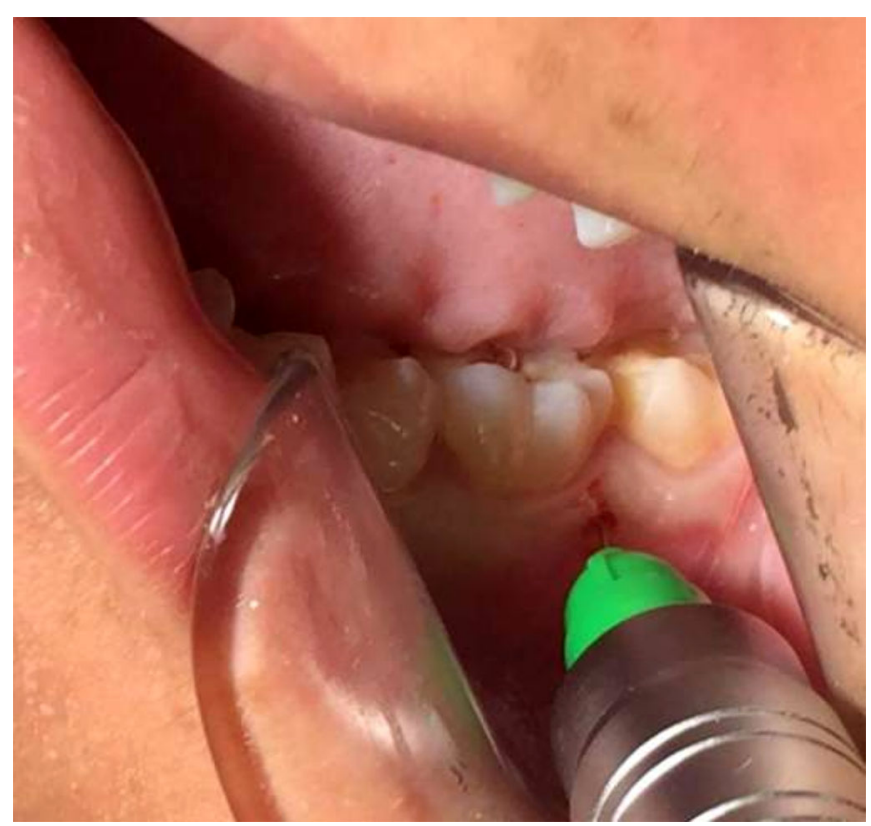

- infiltration of anesthetic into the concellous bone $-0.9 \mathrm{~mL}$ anesthetic (4\% articaine hydrochloride with 1:100 000 adrenaline) was infiltrated for $92 \mathrm{~s}$.

During the IO it was observed for correct infiltration of the anesthetic solution into the spongy bone without backflow through the bone perforation. The endodontic treatment was started immediately after registration of two positive results (100 $\mu \mathrm{A}$ ) of electric pulp testing (Logipex 5, Oviron Electronics, Bulgaria) of treated tooth.

Our goal was to investigate the presence of pain during various parts of endodontic treatment with Visual Analog Scale. The pain level was registered at the end of the following parts of the endodontic treatment:

1st part - after preparation of the endodontic access;

2nd part - after determining the working length for all root canals;

3-rd part - after root canal preparation with Pro Taper Next (Dentsply, Maillefer, Switzerland).

The IO was considered successful in cases where it was possible to complete the preparation of all root canals without any supplemental anesthesia.

Statistical analysis was performed by Statistica 
4.5 (StatSoft, Inc. Microsoft, USA), SPSS 11.5 (Inc, Chicago, IL, USA) Excel 7.0 VB for applications and PraphPad Prism 3.0 (PraphPad, Soft, USA). Data was processed with detailed and comparative statistical analysis.

\section{RESULT}

In table 1 are presented the average age of the patients, the number of the lower molars with irreversible pulpitis and the number of performed IO.

Table 1. Patient's average age, number of molars with irreversible pulpitis and number of performed IO.

\begin{tabular}{|c|c|c|c|c|c|}
\hline \multirow{2}{*}{$\mathbf{N}$} & \multirow{2}{*}{ Average age } & \multicolumn{2}{|c|}{ Irreversible pulpitis } & \multicolumn{2}{c|}{ Performed IO } \\
\cline { 3 - 6 } & & First molar & Second molar & Left & Right \\
\hline 30 patients & 28 years & 16 & 14 & 13 & 17 \\
\hline
\end{tabular}

From the clinical trial were excluded two patients because of technical difficulty in performance of IO and subsequent backflow of anesthetic solution through bone perforation. Results on the pain level during endodontic treatment, reported on 28 patients, are presented in table 2 .

Table 2. Pain level during endodontic treatment.

\begin{tabular}{|c|c|c|c|c|c|}
\hline $\begin{array}{c}\text { Endodontic } \\
\text { treatment }\end{array}$ & $\mathbf{n}$ & $\begin{array}{c}\text { None pain } \\
(\mathbf{0 - 4} \mathbf{~ m m}) \\
\mathbf{n \%}\end{array}$ & $\begin{array}{c}\text { Mild pain } \\
\mathbf{( 5 - 4 4} \mathbf{~ m m}) \\
\mathbf{n \%}\end{array}$ & $\begin{array}{c}\text { Moderate pain } \\
\mathbf{( 4 5 - 7 4} \mathbf{~ m m}) \\
\mathbf{n \%}\end{array}$ & $\begin{array}{c}\text { Severe pain } \\
\mathbf{7 5 - 1 0 0} \mathbf{~ m m}) \\
\mathbf{n \%}\end{array}$ \\
\hline 1-st part & 28 & $\begin{array}{c}28 \text { patients } \\
(100 \%)\end{array}$ & $\begin{array}{c}\text { None } \\
\text { registered }\end{array}$ & $\begin{array}{c}\text { None } \\
\text { registered }\end{array}$ & $\begin{array}{c}\text { None } \\
\text { registered }\end{array}$ \\
\hline 2-nd part & 28 & $\begin{array}{c}28 \text { patients } \\
(100 \%)\end{array}$ & $\begin{array}{c}\text { None } \\
\text { registered }\end{array}$ & $\begin{array}{c}\text { None } \\
\text { registered }\end{array}$ & $\begin{array}{c}\text { None } \\
\text { registered }\end{array}$ \\
\hline 3-rd part & 28 & $\begin{array}{c}21 \text { patients } \\
(75 \%)\end{array}$ & $\begin{array}{c}4 \text { patients } \\
(14,3 \%)\end{array}$ & $\begin{array}{c}1 \text { patient } \\
-3,50 \%\end{array}$ & $\begin{array}{c}\text { patients } \\
(7,2 \%)\end{array}$ \\
\hline
\end{tabular}

No pain was registered either in preparation of endodontic access or in determining the working length for all root canals. Only four patients $(14.3 \%)$ registered mild pain during root canal preparation, which did not interfere of the endodontic treatment. In the 3-rd part of endodontic treatment it was registered moderate and severe pain respectively from $3.5 \%$ and $7.2 \%$ of patients, requiring a supplemental anesthesia.

On figure 4 is presented the percent successful and failed IO in endodontic treatment of mandibular molars.
Fig. 4. Success rate of primary IO.

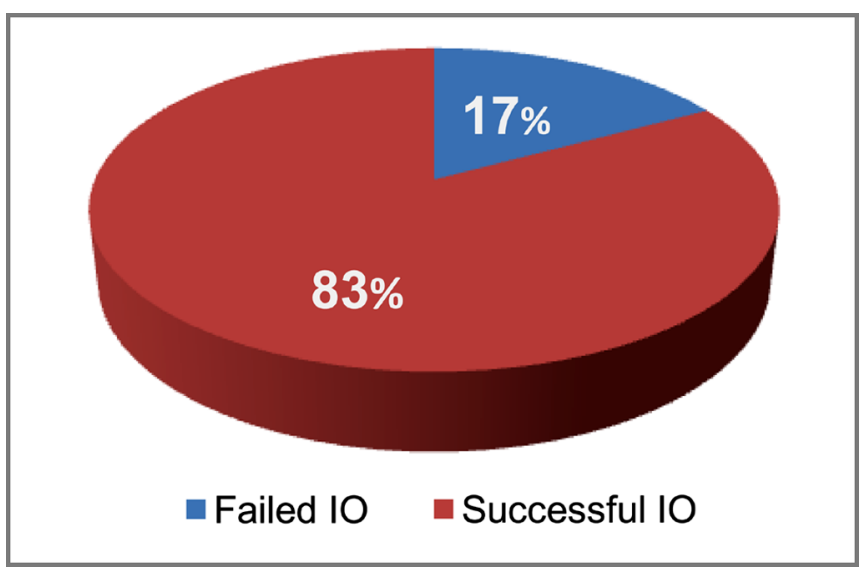

Five of 30 performed IO have been accepted for unsuccessful, 2 of which were due to a difficulty in its technical performance and 3 due to the presence of moderate and severe pain requiring a supplemental anesthesia. 


\section{DISCUSSION}

The intraosseous injection allows the local anesthetic solution directly into the cancellous bone adjacent to the tooth to be anesthetized $[6,7]$. According to the literature, intraosseous infiltration of local anesthetic is an effective method of providing pulpal anesthesia of lower molars with irreversible pulp applied as a supplemental technique to IANB, as well as as primary or supplemental technique of asymptomatic teeth $[8,9]$.

Nowadays the advanced of instrumentation, which allows the slow and painless delivery of local anesthetic solution into spongy bone has led to the development of IO as a primary method of analgesia in dentistry. IO confers many benefits and advantages. As advantages of IO are described rapid onset, smaller doses anestehetic than regional block method, no numbing of soft tissue resulting in very low risk of self-biting and good acceptance by patients [10]. Despite the limited number of studies published on IO in recent years, the existing literature indicates considerable support for its use. Compared to conventional methods, traditional IO injection using computer-controlled devices delivers more effective, efficient, and comfortable anesthesia for limited mandibular procedures (re- storative and endodontic treatment, extraction). Using QuickSleeper, Ozer et al. reported $82.5 \%$ success $(47.5 \%$ higher than IANB) with intraosseous injection using $1,5 \mathrm{~mL}$ of $4 \%$ articaine with $1: 100$ 000 epinephrine. Within children, Sixou et al. reported $91.9 \%$ efficacy using QuickSleeper $(0.8 \mathrm{~mL}$ 4\% articaine with 1:200 000 epinephrine) [11]. The success rate of primary IO with other intraosseous delivery systems is also high. Pereira et al. reported $96.8 \%$ success using $0.9 \mathrm{~mL}$ of $4 \%$ articaine with 1:100 000 epinephrine, Remmers et al. $-87 \%$ success using $1.8 \mathrm{~mL}$ of $2 \%$ lidocaine with 1:100 000 epinephrine, Nusstein et al. - $98 \%$ success using $1.8 \mathrm{~mL}$ of of $2 \%$ lidocaine with 1:100 000 epinephrine.

In our study the registered effectiveness of IO is similar to that reported by number of authors (Coggins, Reploge,Remmers, Sixou) and confirms the high success rate of primary IO in endodontic treatment of mandibular molars with irreversible pulpitis.

\section{CONCLUSION}

The IO can be use as primary method of analgesia that provides reliable pulp anesthesia for routine endodontic treatment.

\section{REFERENCES:}

1. Boopathi T, Sebeena M, Sivakumar K, Harikaran J, Karthick K, Raj A. Supplemental pulpal anesthesia for mandibular teeth. J Pharm Bioallied Sci. 2013 Jun;5(Suppl 1):S103-8. [PubMed] [Crossref]

2. Tortamano IP, Siviero M, Costa CG, Buscariolo IA, Armonia PL. A Comparison of the Anesthetic Efficacy of Articaine and Lidocaine in $\mathrm{Pa}$ tients With Irreversible Pulpitis. $J$ Endod. 2009 Feb;35(2):165-8. [PubMed] [Crossref]

3. Gazal G. Comparison of speed of action and injection discomfort of $4 \%$ articaine and $2 \%$ mepivacaine for pulpal anesthesia in mandibular teeth: A randomized, double-blind cross-over trial. Eur J Dent. 2015 Apr-Jun; 9(2):201-6. [PubMed] [Crossref]
4. Meechan JG. Supplementary routes to local anaesthesia. Int Endod J. 2002 Nov;35(11): 885-96. [PubMed] [Crossref]

5. Wong JK. Adjuncts to Local Anesthesia: Separating Fact From Fiction. J Can Dent Assoc. 2001 Jul-Aug;67(7):391-7. [PubMed]

6. Feridoz J, Raj JD. Intraooseous anesthesia in dentistry - A review. Drug Invention Today. 2018 Jun;10(2):3035-40.

7. Santhosh Kumar MP. Newer delivery systems for local anesthesia in dentistry. J Pharm Sci Res, 2015; 7(5):252-5.

8. Graetz C, Fawzy-El-Sayed KM, Graetz N, Dörfer CE. Root Damage Induced by Intraosseous Anesthesia. An in Vitro Investigation. Med Oral Patol Oral Cir Bucal. 2013 Jan 1;18(1):e130-4.
[PubMed] [ $\underline{\text { Crossref] }}$

9. Claffey E, Reader A, Nusstein J, Beck M, Weaver J. Anesthetic efficacy of articaine for inferior alveolar nerve blocks in patients with irreversible pulpitis. J Endod. 2004 Aug; 30(8):568-71. [PubMed] [Crossref]

10. Sixou JL, Marie-Cousin A. Intraosseous anaesthesia in children with $4 \%$ articaine and epinephrine $1: 400,000$ using computer-assisted systems. Eur Arch Paediatr Dent. 2015 Dec; 16(6):477-81. [PubMed] [Crossref]

11. Tom K, Aps J. Intraosseous anesthesia as a primary technique for local anesthesia in dentistry. Clin Res Infect Dis. 2015 Jan;2(1):1012. 
Please cite this article as: Simeonova E, Tsanova S, Zagorchev P. Effectiveness of primary intraosseous anesthesia in the endodontic treatment of mandibular molars with irreversible pulpitis. J of IMAB. 2020 Apr-Jun;26(2):3063-3067. DOI: https://doi.org/10.5272/jimab.2020262.3063

Received: 14/05/2019; Published online: 08/04/2020

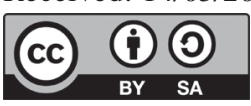

Address for correspondence:

Emiliya Simeonova

Department of Operative Dentistry and Endodontics, Medical University of Plovdiv

3, Hristo Botev Str., Plovdiv, Bulgaria.

E-mail: emisimeonova2003@abv.bg, 